\title{
Penerapan Prinsip Self Determination terhadap Pembentukan Negara Kosovo Ditinjau dari Perspektif Hukum Internasional
}

\author{
Yogi Dwi Saputra*; Ramlan \\ Fakultas Hukum Universitas Jambi \\ *Coresponding author: yogidwisaputra06@gmail.com \\ Submission : 06 Juli 2020 \\ Revision : 31 Oktober 2020 \\ Publication : 20 November 2020 \\ DOI : doi.org/10.36565/up.v1i2.9867
}

\begin{abstract}
On February 17, 2008, the Kosovo parliament proclaimed Kosovo an independent state, leaving Serbia at a parliamentary session attended by 109 members. Previously Kosovo was a province under Serbian rule with an ethnic Albanian majority. The purpose of this research is to find out how international law is regulated regarding the formation of a state using the right to self-determination and what is the importance of recognition in the formation of a country. The research method used is a normative juridical research type. The results showed that the right to self-determination has been recognized as a human right in international law. With this right, every country can determine its political status and freely pursue economic, social and cultural development. However, in international law, self-determination is a type of independence that aims to free oneself from colonialism and foreign powers. Regarding the issue of recognition, it is difficult to separate clearly between political and legal elements because the process of granting and refusing recognition by the state is usually influenced by political factors, while the result is legal binding. The definition or elements of the state is contained in the Montevideo Convention 1933, where recognition is a declarative element and if all constitutive elements have been fulfilled by the political community,
\end{abstract}


then automatically it has become a State and must be treated as such by other States.

Keywords: International Law; Kosovo; State.

\begin{abstract}
Abstrak
Pada tanggal 17 Februari 2008, parlemen Kosovo memproklamasikan Kosovo sebagai negara merdeka, yang lepas dari Serbia pada sidang parlemen yang dihadiri 109 anggota. Sebelumnya Kosovo merupakan provinsi dibawah kekuasaan Serbia dengan mayoritas masyarakat beretnis Albania. Tujuan penelitian ini dimaksudkan untuk mengetahui bagaimana pengaturan hukum internasional mengenai pembentukan negara dengan menggunakan hak menentukan nasib sendiri dan apa arti penting pengakuan dalam pembentukan suatu negara. Metode Penelitian yang digunakan adalah tipe penilitian yuridis normatif. Hasil penelitian menunjukkan bahwa hak untuk menentukan nasib sendiri telah diakui sebagai hak asasi manusia dalam hukum internasional. Dengan hak tersebut setiap negara dapat menentukan status politiknya dan secara bebas mengejar pembangunan ekonomi, sosial dan budaya. Namun dalam hukum internasional, penentuan nasib sendiri adalah sejenis kemerdekaan yang bertujuan untuk membebaskan diri dari penjajahan dan kekuasaan asing. Mengenai masalah pengakuan, sulit memisahkan antara unsur-unsur politik dan hukum secara jelas karena proses pemberian dan penolakan pengakuan oleh negara biasanya dipengaruhi oleh faktor politik, sedangkan akibatnya adalah keterikatan hukum. Definisi atau unsur-unsur negara terdapat dalam Konvensi Montevideo 1933, dimana pengakuan merupakan unsur deklaratif dan apabila semua unsur konstitutif telah dipenuhi oleh masyarakat politik, maka dengan sendirinya ia telah merupakan sebuah Negara dan harus diperlakukan secara demikian oleh Negara-negara lainya.
\end{abstract}

Kata Kunci: Hukum Internasional; Kosovo; Negara.

\title{
A. Pendahuluan
}

Hak Asasi Manusia merupakan hak kodrati, hak dasar manusia, hak mutlak atau dalam bahasa Inggris disebut natural rights, human rights dan fundamental rights. Dalam 
bahasa Belanda dikenal grond rechten, mensen rechten dan rechten van mens. Istilah-istilah tersebut menunjukkan bahwa sebagaimana disebut merupakan bentuk pengakuan adanya hak manusia sendiri. ${ }^{1}$

Dalam era globaliasi saat ini perdagangan internasional menjadi persoalan yang sangat penting, selain berpotensi meningkatkan kemakmuran nasional dan internasional, juga merupakan kekuatan yang dapat dipergunakan sebagai senjata melebihi kekuatan militer sekalipun. Munculnya blokblok perdagangan internasional merupakan bentuk kerjasama internasional yang manfaatnya melampaui persaingan militer dan persaingan wilayah.

Hak Asasi Manusia harus dijunjung tinggi keberadaannya dan diakui oleh setiap orang. Karena itu, dalam rangka menjamin atau melaksanakan hak-hak dasar yang sudah terpatri dalam hukum alam, diperlukan adanya hukum positif yang mengatur akan hal ini. ${ }^{2}$ Pada Deklarasi Universal HAM (Universal Declaration of Human Rights) yang merupakan pengakuan terhadap hak-hak asasi manusia, hak-hak manusia diakui dan dilindungi keberadaannya secara hukum. HAM adalah hak-hak yang dimiliki manusia semata-mata karenamanusia. ${ }^{3}$ Termasuk dari salah satu Hak Asasi Manusia yang tercantum dalam deklarasi ini adalah hak untuk kemerdekaan dan diakui keberadaannya.

Pada hakikatnya kemerdekaan adalah hak setiap manusia dan menjadi hal yang diperjuangkan oleh manusia. Ini adalah bagian dari kodrat manusia, dan tujuannya adalah untuk selalu dapat melaksanakan keinginan dengan bebas

${ }^{1}$ A. Masyhur Effendi.Perkembangan Dimensi Hak Asasi Manusia (HAM) dan Proses Dinamika Penyusunan Hukum Hak Asasi Manusia (HAKHAM).Bogor:GHALIA Indonesia. 2005. hal. 9.

2 Ibid..hal.12

${ }^{3}$ Retno Kusniati. Sejarah Perlindungan Hak Asasi Manusia dalam Kaitannya dengan Konsepsi Negara Hukum.INOVATIF| Jurnal Ilmu Hukum 4.5. 2011. Hal 83. 
tanpa harus dipaksa atau ditekan dan diancam oleh pihak lain yang dianggap menghalangi kebebasan tersebut. Hal inilah yang melatarbelakangi suatu bangsa untuk memperjuangkan kemerdekaannya.

Kemerdekaan pada dasarnya merupakan perwujudan dari hak suatu bangsa untuk menentukan nasibnya sendiri. Hak untuk menentukan nasib sendiri (right to selfdetermination) telah diakui sebagai bagian dari hak asasi manusia (HAM) dan berlandaskan pada hak setiap bangsa (peoples) untuk mendefinisikan status politik dan bebas mengejar pembangunan ekonomi, sosial dan budaya.

Hak tersebutterdapat pada naskah Deklarasi tentang hak dan kewajiban negara-negara 1949yang dimuat dan dinyatakan dalam Pasal 1: "Every State has the right to indenpendence and hence to exercise freely, without dictatation by any other State, all its legal power, including the choice of its own form of government".

Hak untuk menentukan nasib sendiri merupakan suatu prinsip hukum internasional yang muncul sebagai norma dalam berbagai perjanjian internasional tentang HAM tertentu. Hak ini menjelaskan bahwa semua negaraatau bangsa berhak menjalankan sistem politiknya sendiri dan memiliki sistemhukum internal sendiri yang secara terbuka berupaya untuk memajukan pembangunan ekonomi, sosial dan budaya sertamenggunakan sumber daya alam secaraseimbang.

Hak untukmenentukan nasib sendiri adalah hak yang berasal dari masyarakat kolektif. Tujuannya adalah untuk menentukan masa depan politik dan ekonomi suatu Negara dan harusbertanggungjawabberdasarkan hukum internasional. ${ }^{4}$ Prinsip ini mengupayakan agarrakyat di suatu wilayah jajahan bebas memilih status politiknya. Penentuan

${ }^{4}$ Andrey Sujatmoko.Hukum HAM dan Hukum Humaniter.Jakarta:Rajagrafindo Persada. 2015. hal. 141. 
inidapat menciptakan kemerdekaan, mencapai konsensus dengan negara tetangga, secara bebas bekerjasama dengan negara merdeka atau status politik lainnya yang ditentukan secara bebas oleh masyarakat yang bersangkutan.

Hak penentuan nasib sendiri juga memilikifungsi dalammembentuk sebuah negara, melindungi kedaulatan dan kemerdekaannya, serta merumuskan tolak ukur untuk solusi perselisihan dan bidang kedaulatan yang tetap dari negara terhadap sumber lain. ${ }^{5}$

PBB mendefinisikan penentuan nasib sendiri sebagai prinsip hukumdan dimuat dalam "Deklarasi mengenai Pemberian kemerdekaan bagi Rakyat dan Bangsa Terjajah 1960", "Kovenan mengenai Hak Asasi Manusia 1966" hingga "Deklarasi mengenai Prinsip-prinsip Hukum Internasional 1970" yaitu penentuan nasib sendiri merupakan hak dari setiap bangsa. Definisi bangsa atau yang dalam bahasa inggris disebut "people" menurut Black's Law Dictionary, yaitu:

"A nation on in its collective and political capacity. The aggregate or mass of the individuals who constitute the state. In a more restricted sense, and as generally used in constitutional law, the entire body of those citizens of a state or nation who are invested with political power for political purposes."

Jika diterjemahkan ke dalam Bahasa Indonesia adalah: "Sebuah negara dalam hal kapasitas politik dan pengambilan keputusan bersama. Kumpulan dari individu atau massa yang merupakan negara. Dalam pengertian yang lebih terbatas, dan umumnya digunakan dalam konstitusi negara, seluruh bagian penduduk suatu negara atau bangsa yang diikuti dengan kekuatan politik untuk kepentingan politik."

Mengenai hak penentuan nasib sendiri dalam suatu bangsa, dapat dilihat pada kasus deklarasi kemerdekaan

${ }^{5}$ Malcolm N.Shaw.Hukum Internasional.Bandung: Nusa Media. 2013. Hal 1197. 
Negara Kosovo secara unilateral pada tanggal 17 Februari 2008. Sebelum disintegrasi Socialist Federal Republic of Yugoslavia, Kosovo merupakan salah satu provinsi di Yugoslavia yang memiliki 2,2 juta penduduk, 90\% dari mereka adalah etnis Albania. Selama dibawah Rezim Presiden Tito mereka memiliki otonomi yang besar. ${ }^{6}$

Situasi berubah sejak 1989, otonomi dicabut dan etnis Albania (Kasovar Albanians) menjadi target pembersihan etnis kebijakan Serbia. Situasi di Kosovo menjadi perhatian Dewan Keamanan (DK) yang kemudian mengeluarkan Resolusi 1160 pada tanggal 31 Maret 1998 yang memberikan sanksi embargo senjata terhadap pemerintah Federal Republic of Yugoslavia (FRY).7 Dewan Keamanan PBB adalah salah satu dari enam badan utama Perserikatan Bangsa-Bangsa (PBB).Dewan Keamanan memiliki tanggung jawab utama untuk memelihara perdamaian dan keamanan internasional.8Berkaitan dengan hal ini, Dewan Keamanan (DK) juga mewajibkan Federal Republic of Yugoslavia (FRY) bekerja sama dengan etnis Albania menghentikan etnic cleansing dan mencari solusi bersama.

Di samping itu Dewan Keamanan (DK) juga menegaskan kegagalan mencapai itu semua akan memberikan kewenangan pada Dewan Keamanan (DK) untuk mengambil tindakantindakan tambahan. Setelah Resolusi 1160 kekerasan di Kosovo semakin intensif. April 1998 diberlakukan sanksi tambahan. Sekjend PBB, Kofi Annan berunding dengan NATO untuk kemungkinan dilakukannya intervensi militer di Kosovo. ${ }^{9}$

\footnotetext{
${ }^{6}$ Sefriani.Peran Hukum Internasional Dalam Hubungan Internasional Kontemporer. Jakarta:Rajawali Pers. 2016. hal. 59.

${ }^{7}$ Ibid.. Hal 60.

${ }^{8}$ United Nations Security Council

9 Ibid.
} 
Kemerdekaan negara Kosovo ini mengejutkan dunia internasional dikarenakan Kosovo menurutwilayahnya menjadi bagian dari negara Serbia yang keberadaanya dan keabsahannya telah diakui oleh masyarakat internasional; kedua, secara teori, tidak mungkin mendirikan Negara dalam suatu negara, karena melanggar hukum internasional. Deklarasi kemerdekaan menimbulkan kontroversi dan bahkan persoalan baru yang samasulitnya. ${ }^{10}$

Sebelumnya pada tanggal 10 Juni 1999, Kosovo sendiri berada dalam pengawasan Dewan Keamanan PBB menurut Resolusi DK PBB No.1244 yang berisi ketetapan Kosovo masuk dalam wilayah yang dikontrol PBB dan mendapatkan status provinsi otonom. Hal tersebut berlangsung setelah pasukan pakta pertahanan atlantik utara (NATO) melakukan pengeboman untuk menekan mundur tentara Serbia. NATO mengambil keputusan, konflik hanya bisa diredakan dengan melayangkan prajuritpenjaga perdamaian untuk menekan kedua pihak dalam mencari solusi damai. ${ }^{11}$

Dalam kaitan ini, Perserikatan Bangsa Bangsa (PBB) belum menyatakan sikapnyakarena adanya perbedaan antara negara-negara yang menjadi anggota tetap Dewan Keamanan PBB. Amerika, Inggris Prancismenyatakan dukungan, sedangkanCina dan Rusia menentang. Begitu pula sikap berbagai Negara di kawasan Kosovo yang tidak seragam, Bulgaria, Kroasia, Hongaria mendukung, sedangkanSlovakia dan Rumania menentang. ${ }^{12}$

Pada kasus deklarasi kemerdakaan negara Kosovo ini, tidak lepas dari masalah politik dan etnis, dan pembentukan Kosovo menjadi sebuah negara baru harus ditetapkan

\footnotetext{
10 Andrey Sujatmoko.Op.Cit. hal. 139.

11 https://internasional.kompas.com/read/2018/02/17/22555501/hari-inidalam-sejarah-kosovo-deklarasikan-kemerdekaan. Diakses pada 28 Januari 2019.

12

Ibid.
}

Uti Possidetis: Journal of International Law, Vol. 1, No. 2 (2020) 
berdasarkan apakah pengakuan dari negara lain diperlukan. Meskipun diakui oleh negara lain adalah unsur deklaratif, artinya ia bukan merupakan unsur mutlak yang dimiliki oleh negara pada saat ia didirikan. Namun dalam proses Kosovo menjadi sebuah negara, tidak hanya bergantung pada keberadaan penduduk, wilayah dan pemerintahannya, tetapi juga membutuhkan bantuan dan dukungan negara lain.

Dari uraian permasalahan diatas, dan melihat kompleksitas dari permasalahan ini, adalah tujuan penulis untuk mengangkat permasalahan ini sebagai bahan dalam melakukan penelitian atau kajian karya ilmiah dengan "Penerapan Prinsip Self Determination dalam Pembentukan Negara Kosovo Ditinjau dsari Perspektif Hukum Internasional".

\section{B. Metode Penelitian}

Penelitian ini merupakan penelitian hukum normatif (legal research). Menurut Soerjono Soekanto dan Sri Mamudji, penelitian hukum normatif adalah penelitian yang dilakukan dengan cara meneliti bahan pustaka atau data sekunder belaka."13 Dengan menggunakan beberapa pendekatan, yaitu pendekatan perundang-undangan (statute approach), pendekatan historis (historical approach), pendekatan konseptual (conceptual approach).14

13 Soerjono Soekanto dan Sri Mamudji.Penelitian Hukum Normatif Suatu Tinjauan Singkat.Jakarta:CV.Rajawali. Cetakan Pertama.1985. Hal 15.

14 Peter Mahmud Marzuki.Penelitian Hukum. Jakarta:Kencana Prenada Media Grup. 2005. Hal 133. 


\section{Pembahasan dan Analisis}

1. Penerapan Prinsip Self Determination Terhadap Pembentukan Negara Kosovo Berdasarkan Declaration on the Granting of Independence to Colonial Countries and Peoples

Hak menentukan nasib sendiri harus prinsip-prinsip hukum internasional yang dapat ditemukan dalam berbagai perjanjian internasional, terutama ketentuan perjanjian internasional yang berkaitan dengan HAM tertentu yang menyatakan bahwa semua negara atau masyarakat memiliki hak untuk membentuk politiknya sendiri serta secara bebas merumuskan peraturan internalnya untuk mengupayakan pembangunan ekonomi, sosial dan budaya, serta pemanfaatan sumber daya alam secara seimbang.

Pada dasarnya hak menentukan nasib sendiri menyatakan bahwa setiap negara atau bangsa berhak atas kepentingan dalam menjalankan kewajiban-kewajiban menurut Hukum Internasional.15 Internasional memiliki pembatasan secara hukum (legal limit) yaitu hanya ditujukan pada proses dekolonisasi.

Sejak awal 1917, konsep penentuan nasib sendiri telah digunakan sebagai dasar dekolonisasi, dan Rusia mendukung hak penentuan nasib sendiri semua negara, termasuk koloni.Pada akhir Perang Dunia Kedua, Perserikatan BangsaBangsa mengambil kesimpulan tentang konsep penentuan nasib sendiri sebagai bagian dari prinsip meningkatkan hubungan persahabatan antar bangsa.Penentuan nasib sendiri telah menjadi dasar politik dari prinsip-prinsip hukum internasional yang ditetapkan oleh Perserikatan Bangsa-

15 Andrey Sujatmoko.Op.Cit.. hal. 141.

Uti Possidetis: Journal of International Law, Vol. 1, No. 2 (2020) 
Bangsa, dalam prakteknya keinginan untuk menentukan nasib sendiri adalah membebaskan semua orang di bawah penjajahan.

Ideologi ini di adopsi berdasarkan resolusi Majelis Umum PBB terhadap dekolonisasi, pada resolusi 1514 (XV) tahun 1960 "Declaration on the Granting of Independence to Colonial Countries and People". Hal ini diuraikan menjadi dua pengaruh penting. Pertama, prinsip diadopsi sebagai hak masyarakat, dan kedua,mendeskripsikan isi resolusi yang menekankan bahwa:

"All people have the right to self-determination, by virtue of that right they freely determine their political status and freely pursue their economic, social and cultural development".16

Bentuk penentuan nasib sendiri yang pertama adalah the right of internal self determination. Dasar hukum internasional yang diakui dimuat dalam Covenant on Civil and Political Rights1966and Covenant on Economic,Social and Cultural Rights 1966 melegalkan bahwa hak suatu bangsa untuk menentukan nasib sendiri melalui internal self determination dilakukan agar suatu bangsa memperoleh pengakuan status politik, ekonomi, sosial dan kebudayaan dalam kerangka negara yang berdaulat.

Aspek politik, ekonomi, sosial, dan budaya dari hak untuk menentukan nasib sendiri saling terkait dan bergantung.Ketergantungan setiap aspek tersebut dapat

Pasal 1 ayat (1) "International Covenant on Civil and Political Rights"/ICCPR. 
dilihat melalui pengakuan penuh dan penerapan dari setiap aspek tersebut. ${ }^{17}$

a. Aspek Politik

Pengertian hak menentukan nasib sendiri adalah kemampuan sekelompok orang untuk secara kolektif mencerminkan nasib politiknya melaui cara yang demokratis. ${ }^{18}$ Pengertian dari penentuan nasib sendiri termasuk kepada hak suatu bangsa yang tersusun dalam suatu wilayah yang tetap untuk menentukan nasib politiknya dengan cara demokratis, atau hak dari suatu bangsa yang hidup dalam negara yang merdeka dan berdaulat untuk bebas memilih pemerintahannya, untuk memilih institusi perwakilan dan untuk secara berkala memilih perwakilan dengan prinsip kebebasan dan kemerdekaan dalam memilih kandidat ataupun partai politik yang ada.

b. Aspek ekonomi

Dari hak penentuan nasib sendiri pertama kali dimanifestasikan dalam bentuk hak bagi semua bangsa untuk menentukan sistem ekonomi sendiri dalam rezim penerintahan yang berkuasa dengan semangat kemerdekaan dan kedaulatan. Lebih jauh, dari sudut pandang ekonomi, hak tersebut juga termasukpenggunaan secara permanen oleh suatu bangsa kedaulatan atas pemanfaatan sumber daya alam, dan melindungi wilayah mereka dari kegiatan-kegiatan eksploitasi oleh perusahaan multinasional yang dapat merugikan secara ekonomis suku bungsa asli yang mendiami wilayah tersebut. Bagaimanapun juga, penghormatan terhadap prinsip

17 Dajena Kumbaro."The Kosovo Crisis in a International Law Perspectiv:Self determination, Territorian Integrity and the NATO Intervention”.NATO office of International Press. 2001.hal. 22.

18 T.M Franck, "The Emerging Right to Democratic Govermance". American Journal International Law.Vol. 86/46. 1992.Hal. 52. 
kedaulatan harus tetap dapat memberikan jaminan terhadap investasi asing. ${ }^{19}$

c. Aspek sosial

Berarti semua bangsa di dunia berhak memilih dan menentukan sistem sosial di wilayah yang ditempati. Aspek ini berkaitan dengan penegakkan keadilan sosial, yang dimiliki oleh semua negara, termasuk kepemilikan efektif atas hak sosial di setiap bangsa tanpa diskriminasi. ${ }^{20}$

d. Aspek budaya

Mengenai adat istiadat dan budaya masing-masing negara yang merupakan bagian penting dari hak untuk menentukan nasib sendiri.. Ini adalah pengakuan atas hak untuk memperoleh, menikmati dan mewarisi kebudayaan, serta melindungi hak atas pendidikan. ${ }^{21}$

Namun, secara normatif hak menentukan nasib sendiri dimuat dalam beberapa aturan hukum internasional diantaranya, yaitu: Pasal 1 ayat (2) Piagam PBB; Pasal 1 ayat (1) "International Covenant on Civil and PoliticalRights" dan "International Covenant on Economic, Social and Cultural Rights"; Resolusi Majelis Umum PBB Nomor 1514 (XV) 14 Desember 1960tentang Deklarasi Pemberian Kemerdekaan kepada Bangsa dan Negara Terjajah; Resolusi Majelis Umum PBB Nomor 2625 (XXV) 24 Oktober 1970 mengenai Deklarasi tentang Prinsip-prinsip Hukum Internasional tentang Kerjasama dan Hubungan Bersahabat di antara Negara-negara dan Hubungan Bersahabat sesuai dengan Piagam PBB.

Sementara hak untuk menentukan nasib sendiri dalam aspek eksternal (the right of external self-determination)

\footnotetext{
19 Dajena Kumbaro.Op.Cit..Hal. 23.

20 United Nations Document.Report of the Subcommission on Prevention of Discrimination and Protection of Minorities on its Twenty-sixth Session,E/CN.4/1128. 1973.hal. 13(28).

21 Ibid.
} 
berfokus kepada pihak asing atau luar, sebagai langkah konkret yang paling jelas adalah sistem pemerintahan kolonial.Dengan kata lain, mengupayakan penentuan nasib sendiri eksternal di suatu negara agar dapat menjalankan kekuasaannya secara mandiri tanpa campur tangan(undue interference) dari negara lain atau pihak asing. ${ }^{22}$

\section{a. Piagam PBB}

Piagam PBB tidak banyakmenjelaskan aturan terkait "self determination", tetapi Piagam PBB memberikan beberapan doktrin tentang hak penentuan nasib sendiri.Prinsip-prinsip ini dengan jelas diatur pada Pasal 1 ayat (2) dan kemudian Pasal 55 Piagam PBB. Pasal 1 ayat (2) yang menetapkan: "To develop friendly relations among nations based on respect for the principle of equal rights and self determination of people". Pasal 55 yang menetapkan: "to creation of stability and well being which are necessary for peaceful and friendly relation among nations based on respect for the principle of equal right and self determination of peoples..."

Pada Pasal 1 ayat (2) terdapatsalah satu tujuan dari PBB yaitumengembangkan hubungan baik antar bangsa-bangsa atas dasar penghormatan terhadap persamaan hak dan prinsip penentuan nasib sendiri dari rakyat. Dalam Pasal 55 diupayakan standar kehidupan masyarakat dunia, mencari solusi untuk masalah kesehatan dan budaya masyarakat internasional dan penghormatan universal terhadap hak asasi manusia.

Kemudian, pengaturan penentuan nasib sendiri dalam Pasal 1, paragraf 2, dan Pasal 55 Piagam Perserikatan BangsaBangsa dilengkapi dengan Bab XI dari Deklarasi Wilayah Tanpa Pemerintahan Sendiri dan Bab XII tentang Sistem

22 Jawahir Thontowi dan Pranoto Iskandar.Op.Cit.. hal. 148.

Uti Possidetis: Journal of International Law, Vol. 1, No. 2 (2020) 
Perwalian Internasional. Namun, tidak ada satu pun dalam dua bab ini yang memberikan gambaran rinci tentang penentuan nasib sendiri.Dalam Pasal 73 Bab XI Piagam PBB memuatkewajiban negara penguasa terhadap wilayah yang belum memiliki sistem pemerintahan sendiri dalam memajukan hak dari daerah-daerah agar memperoleh pemerintahan sendiri. ${ }^{23}$

\section{b. The United Nation Covenants on Human Rights} (Covenant on Civil and Political Rights 1966 and Covenant on Economic, Social and Cultural Rights 1966)

Kedua, kovenan yang mengatur mengenai self determination memiliki kalimat yang sama. Pasal 1 dari kedua kovenan ini mengakui dan menyetujui isi dari hak untuk mentukan nasib sendiri (self determination) melalui kebijakan berikut:

"1. All people have the right of self determination. By virtue of that right they freely determine their political status and freely pursue their economic, social and cultural development.

2. All people may, for their own ends, freely dispose of their natural wealth and resources without prejudice to any obligations arising out of international economic cooperation, based upon the principle of mutual benefit, and international law. In no case may a people be deprived of its own means of subsistence.

3 The state parties to the present covenant, including those having responsibility for the administration of NonSelf-Governing and Trust Territories, shall promote the realization of the right of self-detremination, and respect that right, in conformity with the provisions of the Charter of the United Nations."

Sefriani.Hukum Internasional Suatu Pengantar.Jakarta:Rajawali Pers. 2010.Hal. 116. 
Komite HAM pada sesi ke-21 dari General Comment ke12 telah memberikan penjelasan terkait. ${ }^{24}$ Self Determination diartikan sebagai "essencial condition" untuk perlindungan HAM serta untuk kemajuan dan peningkatan HAM.Hak untuk menentukan nasib sendiiri mempunyai bagian yang terpisah dari hak-hak lainnya dalam kovenan.Self determination merupakan hak yang tidak dapat ditarik dari setiap bangsa dan memiliki kewajiban timbal balik dimana penerapan dari hak ini tidak dapat dilepaskan dengan aturan hokum internasional lainnya.

Menurut Pasal 1 ayat (1) dari Kovenan Internasional tentang Hak-Hak Ekonomi, Sosial dan Budaya, Setiap orang menikmati kebebasan untuk menentukan status politik, perkembangan ekonomi, masyarakat dan budaya. Dengan kata lain, setiap negara bebas untuk mendirikan institusi politik, mengembangkan sumber daya ekonominya dan menyesuaikan perubahan sosial dan budayanya sendiri tanpa intervensi dari negara lain. Namun, para sarjana hukum internasional telah banyak memberikan saran bahwa hak suatu negara dalam menetapkan status politiknya wajib dicantumkan pada Covenant on the Civil and Political Rights.

Menurut Hassan Wirajuda, dalam Resolusi Majelis Umum PBB No. 1514/1960 dan Kovenan Hak-hak Sipil dan Politik (CCPR) tidak ada pembeda antara "right to" dan "right of self-determination". Dan dalam praktek, keduanya digunakan secara rancu. Pada dasarnya ada dua tingkatan penentuan nasib sendiri, diantaranya: (1) Right to selfdetermination, ini merupakan hak yang bersifat sekali dan tidak terpisahkan untuk membentuk suatu negara; (2) Right of self-determination, ini adalah hak yang bersumber dan juga konsekuensi dari "right to self-determination", yaitu hak untuk

24 United Nations Document.Covenants on Civil and Political Rights General Comment No. XII. Article. 1(1). 
menentukan bentuk negara, sistem pemerintahan sistem ekonomi atau sistem budaya tertentu, yang seluruhnyamerupakan aturan dalam suatu negara.

Oleh karena itu, perwujudan "right to self-determination" dicapai melalui kemerdekaan dalam rangka membentuk atau mendirikan negara ("state") untuk membebaskan diri dari penjajahan atau untukberintegrasi atau berasosiasi dengan negara yang lain. Hal tersebut dilakukan sekali dan untuk selamanya.Sedangkan, perwujudan "right of selfdertermination" dicapai melalui berbagai tindakan negara yang ditujukan otoritas negara berdaulat. ${ }^{25}$

\section{c. Declaration on the Granting of Independence to Colonial Countries and Peoples 1960}

Perkembangan dari hak penentuan nasib sendiri dalam hukum internasional mengarah pada dicantumkannya hak ini ke dalam Resolusi Majelis Umum PBB No. 1514 pada 14 Desember 1960 atau yang lebih dikenal dengan nama The Declaration on Granting Independence to Colonial Countries and People.26Penentuan posisi deklarasi tersebut merupakan interpretasi dari "Piagam PBB" dan realisasi hak untuk menentukan nasib sendiri.Ini adalah dasar untuk memperjuangkan kemerdekaan hanya di wilayah jajahan atau koloni dan bukan di negara yang mencoba melakukan separatisme.27Deklarasi ini memuat prinsip-prinsip penting dan mendasar bagi pelaksanaan hak penentuan nasib sendiri serta kondisi-kondisi yang harus segera dipenuhi oleh penguasa administrasi:

1. Penguasaan/penaklukan bangsa dengan dominasi, eksploitasi merupakan pelanggaran hak asasi

\footnotetext{
25 Andrey Sujatmoko.Op.Cit.. hal. 142.

26 Declaration on Granting Independence to Colonial Countries and People 1960 (GAR 1514).

27 Kumbaro.Op.Cit.. hal. 16.
} 
manusia yang bertentangan dengan Piagam PBB yang dapat menganggu perdamaian dan keamanan seluruh dunia.

2. Semua bangsa mempunyai hak untuk menentukan nasib sendiri untuk secara bebas menentukan status politik dan mengejar pembangunan ekonomi, sosial dan budayanya.

3. Persiapan yang tidak memadai di bidang politik, ekonomi dan sosial bukan alasan untuk menunda kemerdekaan suatu bangsa.

4. Tindakan militer dan penekanan-penekanan lainnya terhadap bangsa yang belum merdeka harus dihentikan untuk memungkinkan pelaksanaan kemerdekaandan keutuhan wilayah nasional secara bebas dan damai.

5. Daerah-daerah perwalian dan wilayah tak berpemerintahan sendiri dan wilayah-wilayah lainnya yang belum memperoleh kemerdekan agar segera dilimpahkan kewenangannya kepada rakyat (bangsa) di wilayah-wilayah tersebut tanpa syarat apapun.

6. Setiap usaha yang ditujukan untuk memecahkan sebagian atau seluruh kesatuan nasional atau keutuhan wilayah suatu negara melanggar tujuan dan prinsip PBB.

7. Semua negara harus melaksanakan ketentuanketentuan dalam Piagam PBB secara sungguhsungguh. Deklarasi hak-hak asasi PBB atas dasar persamaan hak, tidak mencampuri urusan dalam negeri, menghormati hak-hak kedaulatan semua bangsa serta keutuhan wilayahnya. ${ }^{28}$

Declaration on the Granting of Independence to Colonial Countries and Peoples yang diadopsi pada tahun 1960 disetujui oleh 89 negara, 1 tidak setuju dan 9 abstain.Kurangnya kesiapan politik, sosial, ekonomi atau

28 Sefriani.Hukum Internasional Suatu Pengantar.Op.Cit..Hal. 117-118.

Uti Possidetis: Journal of International Law, Vol. 1, No. 2 (2020) 
pendidikan tidak bisa digunakan sebagai protes untuk menunda kemerdekaan, sementara upaya kemerdekaan melalui penentuan nasib sendiri yang dapat menganggu kesatuan nasional dan integritas wilayah suatu negara dianggap tidak sesuai dengan piagam PBB.

Declaration on the Granting of Independence to Colonial Countries and Peoples mengatur syarat penentuan nasib sendiri melalu penekanannya terhadap konteks kolonial dan menentang terhadap segala upaya pemisahan diri dari suatu negara, dan telah dianggap oleh beberapa pihak sebagai interpretasi yang mengikat dari Piagam tersebut. Deklarasi ini diperkuat dengan pembentukan Komite Khusus Dekolonisasi (Special Committee in Decolonization(C24)), yang kini mengurusi semua wilayah dependen dan telah terbukti sangat aktif, dan dengan fakta bahwa hampir semua Resolusi PBB yang berhubungan dengan penentuan nasib sendiri tegastegas menyebutnya. ${ }^{29}$

Shaw juga menyampaikan bahwa the self dalam self determination harus ditetapkan dalam kerangka pengaruh kolonial, usaha-usaha untuk memperluas hal ini tidaklah akan berhasil dan bahwa United Nations has always strenously opposed any attempt at the partial or total disruption of the national unity and territorial integrity of a country. ${ }^{30}$

Dalam pembahasan deklarasi tersebut, pelaksanaan hak penentuan nasib sendiri hanyalah dasar bagi negara kolonial untuk memperjuangkan kemerdekaan bukan upaya untuk separatism, secara bijak diungkapkan dengan kalimat"the necessity of bringing to a speedy and unconditional end colonialism in all its forms and manifestations." 31

Selain kedaulatan dan kemerdekaan, negara juga memiliki yurisdiksi penuh atas seluruh wilayah atau seluruh

\footnotetext{
29 Malcolm N. Shaw.Op.Cit..Hal. 230.

30 Sefriani.Hukum Internasional Suatu Pengantar.Op.Cit.. Hal. 120.

31 Ibid.
} 
wilayah.Oleh karena itu, negara memiliki hak penuh untuk menjaga keutuhan wilayahnya. ("territorial integrity") dari segala ancaman baik dari dalam maupun dari luar.

Dengan demikian yang dilakukan oleh kekuasaan negara atau yurisdiksinya di berbagai wilayahnya adalah lengkap dan eksklusif.Dikatakan lengkap karena suatu negara dapat mengunjungi seluruh wilayah negara, termasuk seluruh penduduk yang tinggal di wilayah tersebut, apapun kebangsaannya.Selain itu, yurisdiksi atas wilayahnya bersifat eksklusif, yang berarti bahwa tidak ada pihak, termasuk negara lain, yang berhak menjalankan yurisdiksi atas wilayahnya.Oleh karena itu, dengan tidak mengurangi penerapan prinsip-prinsip hukum internasional, wilayah suatu negara tidak dapat diganggu gugat ("the inviolability of territories of states"). ${ }^{32}$

Prinsip keutuhan wilayah (territorial integrity) melindungi kerangka wilayah negara-negara merdeka dan menjadi bagian dari konsep kedaulatan negara. Dari sudut konsep pembekuan perbatasan teritorial yang ada pada saat kemerdekaan (kecuali dengan kesepakatan bersama), norma tersebut dinamakan dengan uti posseditis juris. Norma ini menyatakan bahwa batas yang sudah tetap dan yang tengah ada pada waktu kemerdekaan tidak bisa diubah kecuali dengan persetujuan para pihak terkait. ${ }^{33}$

Menurut hukum internasional, Serbia sebagai negara yang berdaulat berhak menekan gerakan separatis di Kosovo.Namun, penindasan pemerintah Serbia terhadap Muslim Albania di Kosovo menimbulkan intervensi internasional (dalam hal ini NATO, PBB, dan Uni Eropa). Tindakan represif yang melanggar norma hukum hak asasi

\footnotetext{
32 Sumaryo Suryokusumo.Hak Negara untuk Mempertahankan Keutuhan Wilayahnya menurut Hukum Internasional.Jurnal Ketahanan Nasional,Vol X, No I. April 2005. Hal. 40.

Malcolm N. Shaw.Op.Cit.. Hal. 275
} 
manusia internasional dan hukum humaniter menyebabkan disintegrasi negara, yang berujung pada deklarasi kemerdekaan Kosovo dari Serbia.

\section{Pengakuan Dari Negara Lain Dalam Pembentukan Negara Kosovo}

Sebagai pelaku utama hubungan internasional, maka yang menjadi perhatian utama hukum internasional adalah hak dan kewajiban serta kepentingan negara. Negara sebagai subjek hukum internasional yang pertama dan utama serta terpenting (par excellence) karena yang pertama menjalan hubungan internasional adalah negara.

Negara sebagai kesatuan politik dalam hukum maka negara harus memiliki unsur-unsur tertentu berdasarkan hukum internasional. Aturan hukum internasional yang disediakan oleh komunitas internasional dapat ditentukan dalam bentuk aturan perilaku, dan negara harus mematuhi aturan perilaku ini saat menjalin hubungan kerja sama.Diantara banyak definisi, terdapat kesepakatan umum di seluruh dunia yang dapat digunakan untuk menentukan definisi atau elemen suatu negara. Media hukum yang "mempersatukan" perbedaan tersebut ialah Montevideo The Convention on Rights and Duties of State of 1933 (Konvensi Montevideo 1933). Menurut Pasal 1 Konvensi tersebut, negara dapat dikatakan utuh harus memilikiempat unsur konstitutif berikut: ${ }^{4}$

1. Adanya penduduk

2. Adanya wilayah (tertentu) atau lingkungan kekuasaan (a definedterritory).

3. Adanya kekuasaan tertinggi (penguasa yang berdaulat), pemerintah yang berdaulat (a government).

4. Kesanggupan mengadakan hubungan dengannegaranegara lainnya.

34 Jawahir Thontowi dan Pranoto Iskandar.Op.Cit..Hal. 105.

Uti Possidetis: Journal of International Law, Vol. 1, No. 2 (2020) 
5. Pengakuan(deklaratif).

\section{Penduduk Tetap}

Merupakan dasar pembentukan sebuah negara.Penduduk atau masyarakat suatu negara adalah sekelompok orang yang tinggal secara permanen atau permanen atau tinggal di suatu wilayah dengan luas tertentu.Boer Mauna mendefinisikan penduduk sebagai kumpulan individu yang terdiri dari dua jenis kelamin.Ras ini tidak membedakan antara ras, bahasa, agama dan budaya.Mereka hidup dalam masyarakat dan mengedepankan keadilan dan politik melalui kewarganegaraan mereka.Hubungan terikat dalam suatu negara. ${ }^{35}$

Tidak ada ketentuan normatifyang menetapkan jumlah penduduk suatu negara. Selain itu tidak ada keharusan suatu negara hanya terdiri dari suatu bangsa, suatu negara dapat terdiri dari beberapa bangsa selama memiliki kewarganegaraan yang sama. ${ }^{36}$

\section{WilayahTertentu}

Wilayah tetap merupakan kebutuhan dasar bagi keberadaan suatu negara. Namun, hukum internasional tidak mengharuskan semua perbatasan bersifat final, dan tidak ada sengketa perbatasan dengan negara tetangga ketika atau setelah menyatakan diri sebagai negara baru. ${ }^{37}$

\section{Pemerintahan}

Sebagai suatu person yuridik, negara membutuhkan banyak institusi untuk mewakili dan menyampaikan

35 Ibid.. hal. 106.

36 Ibid.

37 Sefriani.Hukum Internasional Suatu Pengantar.Op.Cit.. hal. 104.

Uti Possidetis: Journal of International Law, Vol. 1, No. 2 (2020) 
keinginannya.Negara hanya dapat menjalankan kekuasaan ini atas nama kekuasaan melalui organ-organ yang terdiri dari individu-individu. Para pemimpin organisasi ini disebut pemerintah, karena bentuk prasangka ini bervariasi dari satu pemerintah ke pemerintah lainnya.Bagi hukum internasional, wilayah tanpa pemerintahan bukanlah negara dalam arti yang sebenarnya. ${ }^{38}$

Keberadaan pemerintahan yang efektif sangat penting dan merupakan salah satu syarat suatu entitas dapat disebut negara.Efektif artinya pemerintah mempunyai kemampuan nyata untuk menjalankan semua fungsi negara, termasuk menjaga keamanan dan ketertiban dalam negeri serta melaksanakan berbagai komitmen di luar negeri. ${ }^{39}$

\section{Kemampuan Untuk Mengadakan Hubungan dengan Negara Lain}

Ini merupakan unsur ke-4 yang terdapat pada Konvensi Montevideo 1933. Pesatnya perkembangan hubungan antar negara, ketentuan dalam Konvensi Montevideo yang mengandung unsure kapasitas (capacity) tersebut sudah tertinggal dan kedaulatan (souvereignty) sebagai pengganti unsur konstitutif keempat pembentukan negara.40Menurut konsep hukum internasional, kedaulatan mempunyai tiga aspek utama, yaitu: ekstern, intern dan territorial

a. Aspek ekstern kedaulatan adalah setiap negara memiliki hak untuk secara bebas menentukan hubungannya dengan masing-masing negara atau kelompok lain tanpa dibatasi, ditekan atau diawasi oleh negara lain.

b. Aspek intern kedaulatan ialah hak atau kewenangan eksklusif negara untuk menentukan bentuk

\footnotetext{
38 Jawahir Thontowi dan Pranoto Iskandar.Op.Cit..Hal. 109.

39 Ibid.

40 Boer Mauna.Op.cit..Hal. 24.
} 
lembaganya, bagaimana lembaga tersebut beroperasi, dan merumuskan undang-undang yang diinginkan dan dipatuhi..

c. Aspek territorial kedaulatan berarti Negara memiliki kekuasaan penuh atas individu danbenda yang ada di wilayahtersebut. ${ }^{41}$

Secara umum, kedaulatan dapat diartikan sebagai to govern itself (memerintah dirinya sendiri).Negara sebagai entitas tentu memiliki kedaulatan, artinya negara memiliki otoritas tertinggi untuk melakukan segala sesuatu di negaranya. Boer Mauna mengatakan: "Kedaulatan adalah kekuatan tertinggi negara selama tidak melanggar hukum internasional, menjalankan berbagai kegiatan sesuai dengan kepentingannya sendiri. ${ }^{42}$

\section{Pengakuan}

Pengakuan adalah cara mengakui fakta dan kemudian menimbulkan konsekuensi hukum. Peran dari pengakuan ini adalah untuk memudahkan negara-negara terkait dalam melakukan transaksi internasional di masa depan. Memperoleh pengakuan nasional secara otomatis akan menunjukkan bahwa negara menerima hak dan kewajiban hukum dalam hukum internasional. Selain itu, pengakuan diterima oleh negara lain sebagai badan hukum yang bertindak sebagai badan hukum oleh negara lain. ${ }^{43}$ Secara garis besar ada 2 teori tentang pengakuan dalam hukum internasional,yaitu:

1. Teori konstitutif, yaituteori yang menyimpulkan bahwa pengakuan negara lain berdampak pada keberadaan atau pembentukan negara baru.

2. Teori deklaratif atau evidentiary, adalah teori yang pengertiannya pengakuan negara lain hanya untuk

\footnotetext{
41 Ibid.

42 Ibid.

43 Jawahir Thontowi dan Pranoto Iskandar.Op.Cit..Hal. 132.
} 
memperkuat atau memperkuat kondisi yang menunjukkan keberadaan negara yang diakui tersebut. Saat ini, dalam praktiknya, yang paling umum diterima adalah teori ini. Keberadaan suatu negara tetap akan sah secara konstitusional meskipun tidak diakui oleh negaralain. ${ }^{4}$

Ada banyak bentuk pengakuan, diantaranya:

1. Pengakuan defacto

Diberikan kepada negara berdasarkan fakta bahwa pemerintahan negara diakuiada. Pada pengakuan ini pihak pemberi pengakuan meragukanakan keberlangsungannya.

2. Pengakuan dejure

Secara kebiasaan, pengakuan de jure adalah kelanjutan dari pengakuan secara de facto, yaitu ketika suatu negara merasa yakin bahwa negara yang akan diakui secara hukum tersebut telah memenuhi kualifikasi hukum internasional..

3. Pengakuan secaradiam-diam

Pengakuan ini dilakukan dengan caramengirimkan perwakilan diplomatik, mengadakan pembicaraan dengan pejabat atau kepala negara setempat, dan mencapai kesepakatan dengan negara tersebut untuk menjalin hubungan dengan pemerintah baru.Contoh dari pengakuan ini adalah hubungan antara Amerika Serikat dan Republik Rakyat Cina.Meskipun Amerika Serikat belum secara resmi mengakui Republik Rakyat Cina, negara tersebut telah mengadakan negosiasi duta besar di Jenewa sejak tahun 1955.45

Pada tanggal 17 Februari 2008, parlemen Kosovo telah membuat sejarah dengan menyatakan Kosovo sebagai negara

Ibid..Hal. 133.

Ibid..Hal. 135-136.

Uti Possidetis: Journal of International Law, Vol. 1, No. 2 (2020) 
merdeka yang merdeka dari Serbia. ${ }^{46 P e r d a n a}$ Menteri Kosovo, Hashim Thaci, menyampaikan deklarasi tersebut pada pertemuan parlemen yang dihadiri oleh 109 anggota. Sebelumnya, Kosovo adalah sebuah provinsi di bawah pemerintahan Serbia dengan mayoritasetnis Albania.Kosovo mendeklarasikan kemerdekaan pada 1992, tetapi hanya Albania yang mengakui kemerdekaan itu.

Dengan dukungan Amerika Serikat, Kosovo secara sepihak mendeklarasikan kemerdekaan, dan sehari kemudian diakui oleh Norwegia, Denmark, Finlandia, Swedia, Jerman, Italia, Prancis, Inggris, Austria, Albania, Turki, dan Afghanistan. Sementara itu, negara yang menolak untuk mengakui adalah Serbia, Rusia, Spanyol, Rumania, Slowakia, dan Siprus.Bahkan Serbia telah menarik semua diplomat dari negara-negara yang mengakui kemerdekaan Kosovo.Pada beberapa pertemuan Dewan Keamanan PBB, Rusia sebagai anggota secara konsisten memveto untuk tidak memberikan kemerdekaan kepada Kosovo. ${ }^{47}$

Dapat dikatakan bahwa pertimbangan politik merupakan faktor utama yang harus diperhatikan suatu negara untukmengakui negara lain. Perlu dicatat, bahwa Mesir merupakan negara pertama yang secara de facto mengakui kemerdekaan Indonesia (tanggal 23 Maret 1946) yang selanjutnyapada tanggal 18 November 1946 bersama dengan Negara lain sepertiLebanon,Yordania,Syria, Yaman, danSaudi Arabia dalam kerangka Liga Arab mengakui kemerdekaan Indonesia secara de jure. ${ }^{48}$

Namun dalam perkembangannya, masih terdapat dua kelompok ahli hukum internasional yang memiliki pendapat

\footnotetext{
46 http://www.detiknews.com/read/2008/09/20/104308/10093

85/10/pelopor-klaim-sepihak-hak-kemerdekaan.Diakses pada tanggal 24 September 2019 pukul 16:20 WIB.

Ibid.

48 Boer Mauna.Op.Cit..Hal. 78.
}

Uti Possidetis: Journal of International Law, Vol. 1, No. 2 (2020) 
berbeda tentang pengakuan Negara. ${ }^{49}$ Golongan pertama berpendapat bahwa jika semua unsur kenegaraan (adanya rakyat, wilayah dan pemerintahan yang berdaulat serta kemamapuan melakukan hubungan dengan Negara lain) telah dipenuhi, maka secara otomatis ia akan menjadi negara dan harus diperlakukan sebagaimana mestinya oleh Negaranegara lain.

Pengakuan hanyalah tindakan formal untuk menegaskan atau menerima fakta yang ada tersebut.Karena itu, pengakuan tidak menciptakan negara baru.Keberadaan entitas sebagai negara baru disebabkan oleh kemampuannya untuk menjalankan kontrol atas wilayahnya sendiri, bukan karena diakui atau tidak oleh pihak lain. Teori ini sejalan dengan Pasal 3 Konvensi Montevideo 1933 yang menyatakan bahwa eksistensi politik suatu negara bebas dari pengakuan pihak lain. Selanjutnya teori ini juga dikuatkan oleh beberapa putusan pengadilan. Dalam Deutcsche Continental Gas Gesellschaft $v$ Polish State 1929, mahkamah arbitrase menyatakan bahwa: ${ }^{50}$

"according to the opinion rightly admitted by the great majority of writers on international law, the recognition of a state is nor constituive but merely declaratory. The state exist by itself and the recognition is nothing else than a declarition of existence, recognised by the state frow which it emanates..." 51

Kelemahan dari teori deklaratif menurut Alina Kaczorowska adalah menempatkan pengakuan pada titik terendah atau empty formality. Golongan pertama ini disebut sebagai penganut teori deklatoir (declaratory theory).Bila lahirnya suatu negara hanya merupakan peristiwa fakta, maka

\footnotetext{
49 J.L. Brierly.The Law Nations. Clarendon Press. Oxford. 1955.Hal. 114.

50 Sefriani.Hukum Internasional Suatu Pengantar.Op.Cit..Hal. 187.

51 Ibid..Hal. 188.
} 
seharusnya akibat yang ditimbulkannya adalah sebagai berikut:

1. Tidak mungkin menolak lahirnya suatu negara dengan memakai alasan hukum;

2. Lahirnya suatu negara bebas dari pengakuan, dalam hal ini pengakuan tidak ikut campur dalam pembentukan negara. ${ }^{2}$

Golongan kedua mengemukakan bahwa meskipun masyarakat politik telah menyadari unsur kebangsaan, namun tidak serta merta diterima sebagai negara dalam masyarakat internasional. Pertama, harus ada pernyataan dari negara lain bahwa masyarakat politik telah memenuhi syarat menjadi negara. Hanya dengan cara inilah dia dapat menikmati hak untuk menjadi negara baru. Menurut Lauterpacht, pendukung utama teori konstitutif, recognition is quasi judical duty dan bukan an act of arbutrary discreation or a political consession.

Dalam praktiknya teori konstitutif dilaksanakan berlandaskan pertimbangan politik murni, seberapa jauh keuntungan yang akan diperoleh negara yang memberi pengakuan. Amerika menolak mengakui RRC sampai akhir 1978 dengan pertimbangan bahwa pengakuan terhadap RRC tidak akan menguntungkan Amerika Serikat dan dunia bebas secara keseluruhan dan hanya mendorong negara tersebut untuk meluaskan dominasi komunis ke seluruh dunia.53 Beberapa kelemahan dari penerapan teori konstitutif yaitu sebagai berikut:

1. Negara baru yang tidak diakui akan menjadi entitas tanpa hak dan kewajiban berdasarkan hukum internasional sampai diakui.

2. Praktik negara menunjukkan bahwa pemberian pengakuan hanya sebuah tindakan politik demi kepentingan negara yang mengakui.

Ibid.

53 Ibid..Hal 189-190.

Uti Possidetis: Journal of International Law, Vol. 1, No. 2 (2020) 
3. Tidak ada aturan yang jelas tentang berapa jumlah minimum negara yang diperlukan untuk memberikan pengakuan terhadap entitas baru untuk menjadi negara.

4. Ketidakjelasan parameter entitas baru untuk menjadi sebuah Negara.Penilaian yang ada didasarkan pada pertimbangan yang sangat subyektif terhadap kepentingan politikpihak yang mengakui saja.

5. Dapat menciptakan instabilitas suatu negara. ${ }^{54}$

Untuk mengakui suatu negara baru pada umumnya Negara-negara memakai kriteria, antara lain sebagai berikut;

1. Keyakinan adanya stabilitas di Negara tersebut

2. Dukungan umum dari Masyarakat atau Penduduk

3. Kesanggupan dan kemauan untuk melaksanakan kewajiban-kewajiban Internasional..$^{55}$

Pengakuan dalam hukum internasional merupakan persoalan yang sangat kompleks karena juga menyangkut persoalan hukum dan politik.Dalam masalah pengakuan, memang sulit untuk memisahkan secara jelas unsur politik dan hukum, karena pengakuan dan penolakan pengakuan oleh suatu negara biasanya dipengaruhi oleh pertimbangan politik, namun konsekuensinya terkait secara hukum. ${ }^{56}$ Pengakuan internasional kepada suatu Negara, pemerintah atau beligerensi cenderung menonjolkan aspek kepentingan. Ada atau tidaknya suatu kepentingan politik akan berpengaruh terhadap diberikannya atau tidak suatu pengakuan. ${ }^{57}$

Dalam kebanyakan kasus, mengenai kelahiran negara baru, pengakuan adalah kebijakan politik suatu negara yang mengakui negara tersebut dan mungkin memiliki akibat:

\footnotetext{
Ibid..Hal. 191.

Boer Mauna.Op.Cit..Hal. 65.

Ibid.. Hal. 59.

57 Ramlan. Hukum Internasional. Universitas Jambi. Jambi. 2005. hal. 127-128.
} 
1. Pengakuan adalah kebijakan pribadi. Negara bebas untuk mengakui suatu negara tanpa memperhatikan sikap negara lain.

2. Pengakuan adalah suatu discretionary act yaitu suatu negara mengakui negara lain kalau dianggapnya perlu, sebagai contoh;

a. Spanyol baru mengakui Peru setelah 75 tahun negara tersebut memproklamasikan kemerdekaanya.

b. Belanda baru mengakui Belgia pada tahun 1838 setelah negara tersebut merdeka pada tahun 1831

c. Amerika Serikat mengakui Israel hanya beberapa jam setelah negara tersebut lahir tanggal 14 Mei 1948

d. Amerika Serikat mengakui RRC setelah 30 tahun terbentuknya negara tersebut.

Perancis misalnya yang dari tahun 1791 sampai tahun 1875beberapa kali berubah, dari kerajaan, republik, kekaisaran, kembali ke kerajaan dan republik dengan pembentukan Republik III pada tahun 1875, Republik IV tahun 1941, dan semenjak tahun 1958 Republik V tetap merupakan negara Perancis dengan hak-hak dan kewajiban yang sama sebagai subjek hukum internasional dan yang tidak memerlukan lagi pengakuan sebagai negara.

\section{Simpulan}

1. Sebagai prinsip hukum internasional hak menentukan nasib sendiri dapat dijadikan norma dalam berbagai perjanjian internasional tentang hak asasi manusia tertentu.Hak ini mengatur bahwa semua negara (all states) atau bangsa berhak membentuk sistem dan aturan politiknya sendiri.Mereka bebas mengejar perkembangan 
ekonomi, sosial dan budaya mereka sendiri, dan menggunakan sumber daya alam yang mereka anggap tepat.

Prinsip penentuan nasib sendiri memungkinkan rakyat di suatu wilayah jajahan menentukan status politiknya. Penentuan nasib sendiri seperti itu dapat menciptakan kemerdekaan, bergabung dengan negara tetangga, pergaulan bebas dengan negara merdeka atau status politik lainnya yang ditentukan oleh rakyat yang bersangkutan. Hak untuk menentukan nasib sendiri juga terkait dengan pembentukkan negara, menjaga kedaulatan dan kemerdekaan negara, merumuskan standar penyelesaian sengketa.

Konsep hak menentukan nasib sendiri telah menjadi salah satu hak yang diakui dalam hukum internasional. Dalam berbagai lingkungan hukum internasional, hak menentukan nasib sendiri dapat digunakan dalam konteks kolonialisme. Misalnya, di luar latar belakang penjajahan, kelompok kecil yang berbeda cita-cita dengan pemerintah daerah kemudian membentuk gerakan separatis dan menggunakan hak penentuan nasib sendiri untuk memisahkan diri, tidak dapat dibenarkan karena hal ini bertentangan dengan tujuan PBB yang menekankan pentingnya integritas territorial suatu negara yang merdeka dan berdaulat.

Pengakuan hukum internasional merupakan masalah yang sangat rumit, karena juga menyangkut masalah hukum dan politik. Mengenai masalah pengakuan, memang sulit untuk memisahkan secara jelas unsur politik dan hukum, karena proses pemberian dan penolakan pengakuan oleh negara biasanya dipengaruhi oleh faktor politik, dan akibatnya adalah keterkaitan hukum.Kesulitan juga berasal dari fakta bahwa hukum internasional tidak mengharuskan suatu negara untuk 
mengakui negara atau pemerintah lain, sama halnya dengan suatu negara atau suatu pemerintah tidak memiliki hak untuk diakui oleh negara lain. Tidak ada keharusan untuk mengakui seperti juga tidak ada kewajiban untuk tidak mengakui. Seperti dikemukakan Komisi Arbitrase, Konfrensi Perdamaian mengenai Yugoslavia, pengakuan merupakan tindakanyang dilakukan negara dengan hati-hati disaat yang diinginkan dan dalam bentuk yang ditentukannya secara bebas.

\section{Referensi}

\section{Instrumen Hukum}

International Covenant on Civil and Political Rights

Declaration on Granting Independence to Colonial Countries and People 1960

Report of the Subcommission on Prevention of Discrimination and Protection of Minorities on its Twenty-sixth Session, E/CN.4/1128.

Kumbaro, Dajena. "The Kosovo Crisis in a International Law Perspectiv:Self determination, Territorian Integrity and the NATO Intervention". NATO office of International Press. 2001

\section{Buku}

Effendi, A. Masyhur.Perkembangan Dimensi Hak Asasi Manusia (HAM) dan Proses Dinamika Penyusunan Hukum Hak Asasi Manusia (HAKHAM). Bogor: GHALIA Indonesia. 2005.

Sujatmoko, Andrey.Hukum HAM dan Hukum

Humaniter.Jakarta: Rajagrafindo Persada. 2015.

Shaw, Malcolm N. Hukum Internasional. Bandung: Nusa Media. 2013. 
Sefriani.Peran Hukum Internasional Dalam Hubungan Internasional Kontemporer. Jakarta:Rajawali Pers. 2016.

Sefriani.Hukum Internasional Suatu Pengantar.Jakarta: Rajawali Pers. 2010.

Soekanto, Soerjono dan Sri Mamudji.Penelitian Hukum Normatif Suatu Tinjauan Singkat. Jakarta: CV. Rajawali. Cetakan Pertama. 1985.

Marzuki, Peter Mahmud.Penelitian Hukum. Jakarta: Kencana Prenada Media Grup. 2005.

Brierly.J.L.The Law Nations. Clarendon Press. Oxford. 1955. Ramlan.Hukum Internasional.Universitas Jambi.Jambi. 2005.

Thontowi, Jawahir dan Pranoto Iskandar.Hukum Internasional Kontemporer. Bandung: PT. Refika Aditama. 2006.

Mauna, Boer. Hukum Internasional: Pengertian Peranan dan Fungsi Dalam Era Dinamika Global. Bandung: P.T. Alumni. 2003.

\section{Artikel/Jurnal}

Idris, WTO : Perspective of Sustainable Development and Ecolabelling. Jurnal Hukum Internasional Universitas Padjadjaran Bandung, Vol 1, No. 3.Desember 2002.

Kusniati, Retno. Sejarah Perlindungan Hak Hak Asasi Manusia dalam Kaitannya dengan Konsepsi Negara Hukum. INOVATIF/ Jurnal Ilmu Hukum 4.5 (2011). 